\title{
KARAKTERISTIK GURU TELADAN DALAM TINJUAN AL-QURAN SURAH AL-KAHF AYAT 65
}

\author{
Muchlis \\ Sekolah Tinggi Keguruan dan Ilmu Pendidikan (STKIP) Bima \\ Muchlisdarwis06@gmail.com
}

\begin{abstract}
Abstrak
Guru mempunyai peranan yang besar dan strategis dalam proses belajar dan mengajar selain materi (kurikulum) dan metode (sistem kurikulum). Hal ini disebabkan karena guru menjadi subjek terdepan dalam pelaksanaan proses pendidikan. Kehadiran guru dalam proses pembelajaran memiliki peranan yang sangat penting, peran guru itu sampai saat ini masih belum dapat digantikan oleh teknologi sekali pun. Guru adalah sosok yang langsung berhadapan dengan peserta didik dalam mentransfer ilmu pengetahuan dan teknologi, sekaligus mendidik putra bangsa dengan nilai-nilai konstruktif. Oleh karena demikian, maka guru dituntut untuk senantiasa meningkatkan kompetensinya. Al-Quran sebagai pedoman bagi kehidupan manusia dalam segala aspek termasuk pendidikan, juga memberikan rambu-rambu tentang karakteristik yang harus dimiliki oleh seorang guru (terutama guru pendidikan Islam). Di antara kompetensi terpenting yang harus dimiliki oleh seorang guru yang dipahami dari QS al-Kahf: 65 adalah kompetensi keagamaan ('abdun), kompetensi kepribadian (rahmah), kompetensi pedagogik dan kompetensi profesional (' $\mathrm{ilm}$ ).
\end{abstract}

Kata Kunci: Guru, 'abdun, rahmah, 'ilm.

\section{Pendahuluan}

Derdapat tiga elemen penting dalam pengajaran. Pertama ialah materi, kedua ialah guru, dan ketiga ialah metode. Jika diperluas ketiga hal ini menjadi kurikulum, tenaga pendidik, dan sistem kurikulum. Dalam Pondok Pesantern, ada prinsip keterkaitan antara ketiga elemen tersebut: 1) metode lebih penting dari meteri; 2) guru lebih penting dari metode; 3) jiwa guru lebih penting dari guru. Jadi, selain materi dan guru, jiwa guru sangat berpengaruh dalam keberhasilan pengajaran. Karena dengan jiwa keikhlasan dan pengabdiannya, guru akan dapat mewarnai murid. ${ }^{1}$ Oleh karena itu, guru harus terus menerus memperhatikan kualitas diri dalam rangka meningkatkan kualitas pendidikan itu sendiri.

${ }^{1}$ Hamid Fahmi Zarkasyi. Kurikulum Pendidikan. Dalam "Islamia: Jurnal Pemikiran Islam". (Republika: 16 Mei 2013). 
Menurut Abuddin Nata, guru adalah pendidik professional dengan tugas utama mendidik, mengajar, membimbing, mengarahkan, melatih, menilai, dan mengevaluasi peserta didik pada pendidikan usia dini, jalur pendidikan formal, pendidikan dasar, dan pendidikan menengah. Selanjutnya menurut Abuddin Nata dalam literatur kependidikan Islam terdapat sejumlah istilah yang mengacu kepada pengertian pendidik/guru. Istilah tersebut antara lain al-murabbi, almu'allim, al-muzakki, al-ulama, al-rasikhuna fi al-'ilm, ahl al-żikr, al-muaddib, al-mursyid, al-ustaz, ulul al-bab, ulu al-nuha, al-faqih, dan al-muwa'id. ${ }^{2}$ Sedangkan Muhaimin menyebutkan hanya 7 saja yaitu ustaż, mu'allim, murabbiy, mursyid, mudarris, mu'addib, dan muzakki. Lebih lanjut Abuddin Nata mengatakan adanya berbagai istilah sebagaimana tersebut di atas menunjukkan bahwa seorang pendidik/ guru dalam ajaran Islam memiliki peran dan fungsi yang amat luas. ${ }^{3}$

Dalam konteks pendidikan, guru mempunyai peranan yang besar dan strategis. Hal ini disebabkan karena guru menjadi subjek terdepan dalam pelaksanaan proses pendidikan. Guru adalah sosok yang langsung berhadapan dengan peserta didik dalam mentransfer ilmu pengetahuan dan teknologi, sekaligus mendidik putra bangsa dengan nilai-nilai konstruktif. Dengan demikian, guru mengemban misi dan tugas yang berat, sehingga profesi guru dipandang sebagai tugas mulia. Meskipun demikian, dalam realitasnya guru selalu dipandang sebelah mata dan untuk menghibur mereka, digelarilah sebagai pahlawan tanpa tanda jasa. ${ }^{4}$

Kompleksitas masalah yang menyebabkan anak bangsa terdegradasi moralnya juga berjalan seiring dengan cepatnya perkembangan teknologi. Sehingga rasa kebangsaan, rasa gotong royong, jiwa musyawarah mufakat, rasa keadilan sosial, dan kemanusiaan bangsa ini sudah begitu rapuh. Ternyata, matematika tidak mengajarkan kejujuran. Biologi tidak meningkatkan moral. Fisika tidak menanamkan keimanan. ${ }^{5}$ Sehingga kehadiran guru dalam proses pembelajaran memiliki peranan yang sangat penting, peran guru itu sampai saat ini masih belum dapat digantikan oleh teknologi sekali pun seperti radio, televisi, tape recorder, komputer, internet maupun teknologi yang paling modern. Banyak unsur-unsur manusiawi seperti sikap, sistem nilai, perasaan, motivasi kebiasaan dan keteladanan, yang diharapkan dari hasil proses pembelajaran yang semua itu

\footnotetext{
${ }^{2}$ Abuddin Nata, Filsafat Pendidikan Islam (Jakarta: Gaya Media Pratama, 2005), 159-160.

3 Muhaimin, Pemikiran dan Aktualisasi Pengembangan Pendidikan Islam, Cetakan I, (Jakarta: Rajawali Pers, 2011), 173.

${ }^{4}$ Janawi, Kompetensi Guru: Citra Guru Profesional,(Bandung: Alfabeta, 2011), 10.

${ }^{5}$ Hamid Fahmi Zarkasyi. Kurikulum Pendidikan. Dalam "Islamia: Jurnal Pemikiran Islam". Republika: 16 Mei 2013.
} 
tidak dapat dicapai kecuali melalui guru. ${ }^{6}$ Begitu pentingnya peranan pendidik dalam pendidikan, Qomar bahkan menyebutkan pendidik (guru/dosen/ustadz) merupakan jantung dari pendidikan Islam di samping perpustakaan, dan laboratorium. ${ }^{7}$

Bahkan dalam skriptualisme pengajaran Islam, Al-Qur'an bukan hanya berbicara tentang pokok-pokok ajaran tentang Tuhan, Rasul, kejadian dan sikap manusia, alam jagat raya, akhirat, akal dan nafsu, ilmu pengetahuan, amar makruf nahi munkar, pembinaan generasi muda, kerukunan hidup antarumat beragama, pembinaan masyarakat dan penegakan disiplin. Namun Al-Qur'an juga memberikan hikmah keteladan sikap dan budi pekerti yang harus diimplementasikan oleh setiap umat Islam dalam kehidupan beragama, teramsuk berkaiatan dengan keteladaan seoreang ahli ilmu dalam mengajara dan membejarkan ilmunya kepada sesama manusia. Meskipun secara konteks, ajaran al-Qur'an tampil dalam sifatnya yang global, dan general. Untuk dapat memahami ajaran al-Qur'an tentang berbagai masalah, maka seseorang harus melewati jalur tafsir sebagaimana yang telah dilakukan para ulama. ${ }^{8}$ Di antara masalah yang membutuhkan tuntunan dari al-Qur'an adalah tentang bagaimana karakteristik guru teladan, sebagaimana tersirat dalam teks Al-Qur'an dalam surah Al-Kahf/18 ayat 65 beriku tini.

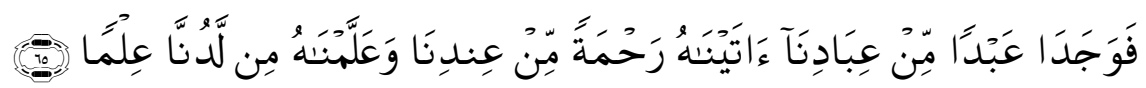

Terjemahannya:"Lalu mereka bertemu dengan seorang hamba di antara hamba-hamba Kami, yang telah Kami berikan kepadanya rahmat dari sisi Kami, dan yang telah Kami ajarkan kepadanya ilmu dari sisi Kami”.

\section{Term Penting dari Quran Surah Al-Kahf: 65}

\section{1. 'Abd (Hamba)}

Kata ini berasal dari kata عبد - يعبد - عبادة ('abada-ya'budu-'ibadatan) yang berarti beribadah, hamba sahaya, budak. ${ }^{9}$ Kata ini terdiri dari kata 'Ain (ع) ba (ب) dan dal (د), yang memiliki beberapa makna yaitu kehalusan, keramahan, kerendahan, kehinaan, dan kekerasan dan kekejaman. ${ }^{10}$ Kata hamba dalam al-

${ }^{6}$ Ahmad Izzan dan Saehudin, Tafsir Pendidikan, Studi Ayat-ayat Berdimensi Pendidikan, Cetakan I, (Tangerang: Pustaka Aufa Media, 2012), 161.

${ }^{7}$ Mujammil Qomar, Strategi Pendidikan Islam, (Jakarta: Erlangga, 2013), 143-144

8 Abuddin Nata, Tafsir Ayat-ayat Pendidikan (Tafsir al-Ayat al-Tarbawy), Cetakan I, (Jakarta: PT Raja Grafindo Persada, 2002.), 1-2.

9 Ahmad Warson Munawwir, Al-Munawwir Kamus Arab Indonesia, Cet. XIV, (Surabaya: Pustaka Progressif, 1997), 886- 887.

${ }^{10}$ Abi Al-Husain Ahmad bin Faris bin Zakariya, Mu'jam Maqayis al-Lugah, Juz 4, (Beirut: Dar al-Fikr, 1979 M/1399H), 205. 
Qur'an dan seluruh kata seakar dengannya disebut 275 kali. ${ }^{11}$ Ada beberapa bentuk perubahan kata hamba dalam al-Qur'an yang memiliki makna berbeda diantaranya عبد ('abdun), عبادة ('ibadah), عباد ('ibad), dabid).

Kata 'abdun dalam kitab Maqayis al-Lugah bahwa dapat dipahamai sebagai kata yang bersifat pasif dan penyembahannya masih bersifat umum, bisa saja dia sebagai hamba yang menyembah jabatan, berhala dan benda-benda lainnya selain Allah SWT. ${ }^{12}$ Menurut Ibnu Manzur, kata ini memiliki dua arti. Pertama, al-Insan (الإنسان), artinya manusia, baik yang statusnya hamba sahaya atau merdeka. Ini adalah arti 'abd secara umum. Kedua, al- 'abd artinya hamba sahaya. ${ }^{13}$ Sibawaih yang dikutip M. Quraish Shihab mengatakan, pada mulanya kata 'abd adalah kata sifat, kemudian digunakan sebagai nama. Di dalam bentuk kata kerja, 'abada berarti menundukkan diri atau menampakkan kehinaan atau kerendahan hati (al-'Ubudiyah). ${ }^{14}$

Al-Asfahani menambahkan bahwa 'ibadah lebih tinggi nilainya daripada 'ubudiyah. Di dalam ibadah, manusia sebagai hamba menampakkan puncak ketundukan dan kepatuhannya dengan melahirkan kerendahan dirinya kepada Tuhan. Seorang hamba adalah seorang yang taat dan tunduk kepada tuannya, tanpa menolak, membantah, atau membangkang perintahnya. ${ }^{15}$ Kata 'ibad memiliki arti sama yaitu hamba. Namun, dalam pemaknaannya yaitu kata yang bersifat aktif yang senantiasa beribadah kepada Allah swt. dan mengingat Allah bagaimanapun keadaannya. Penisbahan kata 'ibad hanya diberikan kepada orang yang senantiasa menyembah Allah SWT. ${ }^{16}$ Kata 'abid memiliki arti penyembah berhala. ${ }^{17}$ Di dalam al-Quran kata ini memiliki konotasi yang jelek seperti menyifati orang-orang kafir dan orang yang bermaksiat kepada Allah. Seperti dalam QS Ali 'Imran/3:181 dan 182, al-Anfal/8: 51- 52. ${ }^{18}$ Dengan demikian, ciri yang melekat dalam diri seorang hamba secara umum disebut dengan 'abdun, adalam dalam bentuk atau wujud penyembahan kepada Allah SWT yang disebut dengan 'ibadah. Hamba yang taat beribadah kepada Allah disebut 'ibad dan hamba kafir disebut dengan 'abid. Secara umum hamba dapat diidentikkan dengan sesuatu yang bentuknya ketundukan kepada seseorang atau penguasa.

${ }^{11}$ Muhammad Fuad 'Abd al-Baqi, Mu jam al-Mufahras li al-Faz al-Qur'an, Cet. I, (Kairo: Dar al-Kutub al-Mishriyah, 1364 H), 441.

${ }^{12}$ Abi Al-Husain Ahmad bin Faris bin Zakariya, Mu'jam Maqayis al-Lugah...., 205.

${ }^{13}$ Muhammad bin Mukrim bin Manzur al-Fariqi al-Misri, Lisan al-'Arabi, Juz 3, Cet. I, (Beirut: Dar Sadir, t.th), 273.

${ }^{14}$ M. Quraish Shihab, Ensiklopedia al-Qur'an: Kajian Kosa Kata, Cet. I, (Jakarta: Lentera Hati, 2007), 323.

${ }^{15} \mathrm{Abi}$ al-Qasim al- Husain bin Muhammad al-Ma'ruf Bi al-Ragib al-Ashfahani, AlMufaradat fi Garib al-Qur'an, Juz 2, (Beirut:Dar Fikr, t.th), 415.

${ }^{16}$ Abi Al-Husain Ahmad bin Faris bin Zakariya, Mu'jam Maqayis al-Lugah....., 205.

${ }^{17}$ Ahmad Warson Munawwir, Al-Munawwir Kamus Arab Indonesia....., 887.

${ }^{18} \mathrm{Abi}$ al-Qasim al- Husain bin Muhammad al-Ma'ruf Bi al-Ragib al-Ashfahani, AlMufaradat fi Garib al-Qur'an...., 415 


\section{Rahmah}

Kata Rahmah terdiri dari tiga huruf $r a$ ', ha', dan mim. Kata rahmah adalah mashdar dari kata (rahima-yarhamu-rahmatun) رحم - يرحم - رحمة ' رحمu . Menurut Ibnu Faris, setiap kata Arab yang berakar dari tiga huruf $\mathrm{ra}^{\prime}, \mathrm{ha}^{\prime}$, dan mim memiliki arti dasar kelembutan hati, belas kasih, dan kehalusan. ${ }^{19}$ Sedangkan menurut al-Ashfahani, kata rahmah berarti belas kasih yang menuntut kebaikan kepada yang dirahmati. Kata ini kadang-kadang dipakai dengan arti ar-riqat al-mujarradah (belas kasih semata-mata) dan kadang-kadang dipakai dengan arti al-ihsan al-mujarrad duna ar-riqah (kebaikan semata-mata tanpa belas kasih). Lebih lanjut Al-Ashfahani mengatakan bahwa rahmah yang datangnya dari Allah adalah in'am (karunia/anugerah), dan ifdhal (kelebihan) ${ }^{20}$. Ibn Manzhur menyebutkan bahwa orang Arab membedakan antara kata rahmah yang disandarkan kepada anak cucu Adam dengan yang disandarkan kepada Allah. kata rahmah yang disandarkan kepada anak cucu Adam adalah riqqat al-qalb wa 'athfih (kelembutan hati dan belas kasihnya), sedangkan kata rahmah yang disandarkan kepada Allah adalah 'athfuh wa ihsanuhu wa rizquh (belas kasih, kebaikan dan rezeki-Nya). ${ }^{21}$ Dalam al-Quran, kata rahmah disebutkan sebanyak 145 kali. Kesemuanya mempunyai beragam makna sesuai dengan konteks pembicaraannya. Setidaknya ada 14 makna bagi rahmah dalam al-Quran ${ }^{22}$, yaitu:

a. Rahmah bermakna agama Islam. Makna ini bisa kita dapati dalam QS alInsan [76]: 31, QS al-Syura [42]: 8, QS al-Fath [48]: 25, QS al-Baqarah [2]: 105, dan QS Ali Imran [3]: 74.

b. Rahmah bermakna surga. Makna ini bisa kita jumpai dalam QS Ali Imran [3]: 107, QS al-Nisa' [4]: 175, QS al-Jatsiyah [45]: 30, QS al-Baqarah [2]: 218 dan QS al-'Ankabut [29]: 23.

c. Rahmah berarti hujan. Makna ini bisa kita jumpai dalam al-Quran antara lain: QS al-A'raf [7]: 57, QS al-Furqan [25]: 48, QS al-Syura [42]: 28, QS al-Rum [30]: 50, dan QS al-Rum [30]: 46.

d. Rahmah berarti kenabian. Makna ini bisa kita jumpai dalam QS Shad [38]: 9, QS al-Zukhruf [43]: 32.

e. Rahmah bermakna nikmat. Makna ini bisa kita jumpai dalam QS Maryam [19]: 2, QS al-Kahf [18]: 65.

f. Rahmah berarti al-Quran. Makna ini bisa kita jumpai dalam QS al-Isra' [17]: 82, QS Yunus [10]: 58, dan QS Yusuf [12]: 111.

g. Rahmah bermakna rezeki. Makna ini bisa kita jumpai dalam QS al-Isra' [17]: 100, QS Fathir [35]: 2, QS al-Isra' [17]: 28, QS al-Kahf [18]: 16 dan QS al-Kahf [18]: 10.

${ }^{19}$ Abi Al-Husain Ahmad bin Faris bin Zakariya, Mu'jam Maqayis al-Lugah, Juz 4, (Beirut: Dar al-Fikr, 1979 M/1399H), 498.

${ }^{20}$ Al-Ashfahani, Al-Mufaradat fi Garib al-Qur'an..., 196.

${ }^{21}$ Ibn Manzhur, Lisan al- 'Arab, (Kairo: Dar al-Ma'arif, 1119), 1612.

${ }^{22} \mathrm{https}$ ///www.harakatuna.com/makna-rahmat-dalam-al-quran-al-karim.html diakses 03 Desember 2018, pukul 10.30 . 
h. Rahmah berarti pertolongan dan kemenangan. Makna ini bisa kita jumpai dalam QS al-Ahzab [33]: 17.

i. Rahmah bermakna sehat dan 'afiyat. Makna ini bisa kita jumpai dalam QS al-Zumar [39]: 38

j. Rahmah berarti cinta. Makna ini bisa kita jumpai dalam QS al-Hadid [57]: 27 dan QS al-Fath [48]: 29.

k. Rahmah bermakna keimanan. Makna ini bisa kita jumpai dalam QS Hud [11]: 28, QS Hud [11]: 63.

1. Rahmah berarti taufik (pertolongan untuk amal kebaikan). Makna ini bisa kita jumpai dalam QS al-Baqarah [2]: 64, QS al-Nisa' [4]: 83, QS al-Nur [24]: 10, QS al-Nur [24]: 14, QS al-Nur [24]: 20 dan QS al-Nur [24]: 21.

m. Rahmah berarti Nabi Isa as. Makna ini bisa kita jumpai dalam QS Maryam [19]: 21

n. Rahmah bermakna Nabi Muhammad saw. Makna ini bisa kita jumpai dalam QS al-Anbiya' [21]: 107.

\section{3. 'Ilm}

Dalam al-Qur'an kata ilmu ternyata banyak disebut, yaitu sebanyak 105 kali. Akan tetapi jika digabung dengan kata derivasinya ia disebut tidak kurang dari 744 kali. Untuk menyebutkan secara terinci, kata-kata turunan itu disebut dalam bentuk dan frekuensi sebagai berikut; 'alima (35), ya 'lam (215), i 'lam (31), yu 'lam (1), 'ilm (105), 'alim (18), ma lum (13), 'alamin (73), 'alam (3), 'alam (49), 'alim/'ulama' (163) 'allam (4) 'allama (12), yu'alim (16), 'ulima (3), mu'allam (1), ta'allama (2). Dari kata turunan itu timbul berbagai pengertian, seperti: mengetahui, pengetahuan, orang yang berpengetahuan, yang tahu, terpelajar, paling mengetahui, memahami, mengetahui segala sesuatu, lebih tahu, sangat mengetahui, cerdik, mengajar, belajar, orang yang menerima pelajaran/diajari, mempelajari; juga pengertian-pengertian seperti tanda ('alam), alamat, tanda batas, tanda peringatan, segala kejadian alam, segala yang ada dan segala yang dapat diketahui. ${ }^{23}$

Sumber ilmu dalam Islam adalah; 1) khabar shadiq, merupakan informasi yang berasal dari atau disandarkan pada otoritas, yaitu wahyu (al-Quran dan alHadits); 2) persepsi indra, persepsi yang digunakan manusia untuk memperoleh ilmu meliputi kelima indra (pendengar, pelihat, perasa, pencium penyentuh) dan; 3) proses akal sehat. Proses akal mencakup nalar (nazhar) dan alur pikir (fikr). Dengan nalar dan pikir ini manusia bisa berartikulasi, menyusun proposisi, menyatakan pendapat, berargumentasi, melakukan analaogi, membuat keputusan

${ }^{23}$ Dawam Raharjdo, Ensiklopedi al-Qur'an, (Jakarta: Paramadina, 1996), 531. Lihat juga Abdurrahman Saleh Abdullah, Teori-teori Pendidikan Berdasarkan al-Qur'an (Jakarta: Rineka Cipta, 2007), 90-91. 
dan menarik kesimpulan. ${ }^{24}$ Sedangkan objek ilmu dalam Islam ${ }^{25}$ itu mencakup dua bagian pokok, yaitu: 1) alam materi (alam semesta beserta isinya). 2) alam non-materi.

Al-Qur'an dan Sunnah tidak melulu berbicara tentang ilmu, tapi juga obyek ilmu yaitu alam semesta dan subyeknya yaitu manusia. Artinya al-Qur'an dan Sunnah mengandung bakal konsep (seminal concept) tentang al-ilm, al-alim (manusia) dan al-ma'lum (alam semesta) yang saling berkaitan. Dan yang terpenting dari seluruh kegiatan keilmuan manusia sebagai al-alim (yang mengetahui) adalah keterkaitannya yang terus menerus dengan al-Aliim (Yang Maha Mengetahui). Oleh sebab itu para ulama mengartikan kata 'aqala (berfikir, mengikat) dengan mengikat ilmu-ilmu yang kita peroleh dari pengamatan kita terhadap alam dengan al-Aliim (Sang Pencipta alam). Perintah "Bacalah dengan namaTuhanmu yang Menciptakan" mengandung arti agar kita mengkaitkan bacaan kita terhadap alam semesta ini dengan Tuhan. ${ }^{26}$

\section{Karakteristik Guru Ideal: Kompetensi, Syarat Dan Sifat}

Kata karakteristik berasal dari kata karakter yang memiliki beberapa arti seperti tabiat; sifat-sifat kejiwaan, akhlak atau budi pekerti yang membedakan seseorang dengan yang lain; watak. Sementara kata karakteristik berarti mempunyai sifat khas sesuai dengan perwatakan tertentu. ${ }^{27}$ Dengan demikian, Karakter adalah satu kualitas atau sifat yang tetap terus-menerus dan menetap yang dapat dijadikan ciri untuk mengidentifikasikan seorang pribadi.

Guru merupakan jabatan atau profesi yang memerlukan keahlian khusus sebagai guru. Pekerjaan ini tidak bisa dilakukan oleh orang yang tidak memiliki keahlian untuk melakukan kegiatan atau pekerjaan sebagai guru. Orang yang pandai berbicara dalam bidang-bidang tertentu belum dapat disebut guru. Untuk menjadi guru diperlukan syarat-syarat khusus, apalagi sebagai guru professional yang menguasai betul seluk-beluk pendidikan dan pengajaran dengan berbagai pengetahuan lainnya yang perlu dibina dan dikembangkan melalui masa pendidikan tertentu atau pendidikan prajabatan. ${ }^{28}$ Keahlian khusus yang harus

24 Syamsuddin Arif. Filsafat Ilmu Islami. Dalam "Islamia: Jurnal Pemikiran Islam". Republika:21 Februari 2013.

${ }^{25}$ M. Quraish Shihab, Wawasan al-Qur'an; Tafsir Tematik Atas Pelbagai Persoalan Umat, (Bandung: Mizan, 2014), 574.

26 Hamid Fahmi Zarkasyi. Membangun Peradaban Islam Dengan Ilmu Pengetahuan. Makalah Kuliah Umum disampaikan pada Pembukaan Program Pasca Sarjana Bidang Pendidikan Islam, Universitas Ibn Khaldun, Bogor, Kampus Universitas Ibn Khaldun , Bogor, tanggal 11 Agustus 2007. 2008), 639

${ }^{27}$ Tim Penyusun Kamus Pusat Bahasa, Kamus Bahasa Indonesia, (Jakarta: Pusat Bahasa,

${ }^{28}$ Uzer Usman, Moh., Menjadi Guru Profesional. (Bandung : Remaja, 2001), 5. 
dimiliki oleh guru adalah istilah lain dari kompetensi. Menurut Undang-Undang ${ }^{29}$ Republik Indonesia nomor 14 Tahun 2005 tentang Guru, Bab IV, Pasal 10, ditegaskan bahwa kompetensi guru meliputi kompetensi pedagogik, kompetensi kepribadian, kompetensi sosial, dan kompetensi professional yang diperoleh melalui pendidikan profesi. Menurut Hamruni sebagaimana dikutip Fahturrahman dan Sulistyorini ${ }^{30}$, kompetensi pendidik dalam pendidikan Islam yaitu: a) Kompetensi personal-religius, b) Kompetensi sosial-religius, c) Kompetensi profesional-religius, serta d) Kompetensi pedagogik-religius.

Kompetensi lain yang perlu diperhatikan oleh seorang guru (khususnya guru pendidikan agama Islam) adalah kompetensi keagamaan. Adapun yang dimaksud dengan kompetensi keagamaan adalah keyakinan dan hubungan transendental seorang pendidik dengan Allah SWT., komitmen beragama pendidik, baik berupa nilai-nilai, maupun yang ditunjukkan dengan perilaku beragama dari seorang pendidik. ${ }^{31}$ Soewarno sebagaimana yang dikutip Khoiron Rosyadi $^{32}$, mengusulkan enam syarat yang harus dimiliki setiap pendidik, yaitu:

a. Kedewasaan. Salah satu ciri kedewaan adalah kewibawaan, dan kewibawaan bersumber pada kepercayaan dan kasih sayang antara pendidik dan anak didik.

b. Identifikasi norma, artinya menjadi satu dengan norma yang disampaikan kepada anak.

c. Identifikasi dengan anak, artinya pendidik dapat menempatkan diri dalam kehidupan anak hingga usaha pendidik tidak bertentangan dengan kodrat anak.

d. Knowledge, mempunyai pengetahuan yang cukup perihal pendidikan.

e. Skill, mempunyai ketrampilan mendidik.

f. Attitude, mempunyai sikap jiwa yang positif terhadap pendidikan.

Menurut Ahmad Tafsir ${ }^{33}$, sifat-sifat dari seorang guru adalah: a) Kasih sayang kepada anak didik; 2) Lembut hati; 3) Rendah hati; 4) Menghormati ilmu yang bukan pegangannya; 5) Adil; 6) Menyenangi ijtihad; 7) Konsekuen, perkataan sesuai dengan perbuatan; 8) Sederhana.

\footnotetext{
${ }^{29}$ Mendikas, Undang-Undang RI Nomor 14 tahun 2005 tantang Guru dan Dosen, Cetakan I, (Yogyakarta: Pustaka Yustisia, 2006), 10.

30 Muhammad Fathurrahman, dan Sulistyorini, Meretas Pendidikan Berkualitas dalm Pendidikan Islam (Menggagas Pendidik atau Guru yang Ideal dan Berkualitas dalam Pendidikan Islam), Cetakan I, (Yogyakarta: Teras, 2012), 122.

${ }^{31}$ Muchlis. Kompetensi Pendidik Dalam Pendidikan Islam Perspektif Al-Qur'an (Telaah Tafsir Al-Mishbah Surah Al-'Alaq). Tesis: Tidak dipublikasikan, 80.

${ }^{32}$ Khoiron Rosyadi, Pendidikan Profetik, (Yogyakarta: Pustaka Pelajar, 2004), 181-182.

${ }^{33}$ Ahmad Tafsir, Ilmu Pendidikan dalam Perspektif Islam, (Bandung: Remaja Rosdakarya, 2008), 84.
} 


\section{Karakteristik Guru Ideal Dalam Qs Al-Kahf: 65}

\section{Ahli Ibadah /'Abdun (Kompetensi Keagamaan)}

Menurut Jumhur Ulama, kata 'abdun yang dimaksud dalam ayat ini adalah Nabi Khidir 'alaihissalam. ${ }^{34}$ Akan tetapi, dalam ushul fiqh ada salah satu kaidah yang berlaku yaitu (العبرة بعموم اللفظ لابخصوص السبب “yang dianggap adalah lafazh yang umum, bukan sebab yang khusus $)^{35}$. Dengan demikian, meskipun ayat ini berbicara tentang Nabi Khidir 'alaihissalam, bisa kita ambil makna umumnya dari kata 'abdun yaitu hamba secara umum. Nabi Khidir 'alaihissalam sebagai seorang guru bagi Nabi Musa 'alaihissalam adalah pribadi yang disebut oleh Allah sebagai 'abdun. Sehingga siapa pun yang memiliki tugas sebagai salah seorang pendidik/guru, maka dia harus memiliki kesadaran bahwa dia adalah seorang 'abdun (hamba). Kesadaran posisi sebagai hamba inilah adalah sebagai representasi dari kompetensi keagamaan. Bagi seorang guru (terutama guru pendidikan Islam), kompetensi keagamaan akan dan harus menjadi ruh (semangat) bagi setiap aktivitas kependidikannya. Tugas keagamaan (berupa 'ibadah) adalah tugas yang ada terlebih dahulu di atas tugas-tugas lainnya, termasuk tugas kependidikan. Kompetensi ini juga akan menjadi pengontrol dalam membangun dan mengaplikasikan kompetensi-kompetensi yang lainnya.

Guru haruslah orang yang mampu mandiri dalam memenuhi tugasnya sebagai hamba Allah ('abdullah) dan khalifah Allah (khalifah fil ardh) dan mampu melaksanakan tugas sebagai makhluk sosial dan sebagai makhluk individu yang mandiri. ${ }^{36}$ Guru yang menyadari posisinya sebagai 'abdun (kompetensi religius) maka akan melahirkan karakter yang baik, diantaranya: a) Guru yang senantiasa melaksanakan shalat ('ibadah) akan selalu mendekatkan diri kepada Allah dalam setiap aktivitasnya, termasuk aktivitas dalam dunia pendidikan. b) Guru akan selalu mendasari aktivitas keguruannya demi dan karena Allah (ikhlas); c) Guru akan mengajarkan dan menjelaskan petunjuk/nilainilai yang terkandung dalam al-Qur'an dan al-Sunnah kepada peserta didik. d) Guru akan selalu mengajarkan, mempraktekkan, memperjuangkan kebenaran. e) Guru akan selalu menampilkan sikap ihsan, merasa selalu diawasi oleh Allah.

\section{Rahmah (Kompetensi Kepribadian)}

Karakteristik ideal yang harus dimiliki oleh guru diantaranya adalah rahmah. Karakter ini jika dikaitkan dengan kompetensi, maka masuk dalam kategori kompetensi kepribadian. Sebagaimana arti dasar dari kata rahmah adalah

\footnotetext{
${ }^{34}$ Wahbah az-Zuhayliy, Tafsir al-Munir: fi al-Aqidah wa asy-Syari'ah wa al-Manhaj, Jilid 8: Juz 15-16, (Damaskus: Daarul Fikr, 2009), 315.

${ }^{35}$ Manna' al-Qaththan, Pengantar Studi Ilmu Al-Quran, (Jakarta: Pustaka Al-Kautsar, 2006), 102

${ }^{36}$ Bukhari Umar, Ilmu Pendidikan Islam, Cetakan I, (Jakarta: Amzah, 2010), 83.
} 
kelembutan, kehalusan dan kasih sayang. Sebagaimana menurut Ahmad Tafsir, rahmah ini adalah sifat dasar yang harus selalu melekat dalam diri seorang guru. Segala proses pendidikan yang dijalankan oleh seorang guru, harus diwarnai oleh sifat ini. Guru harus memiliki sifat kasih sayang kepada peserta didik karena dengan demikianlah mereka dapat menerima pendidikan dan pengajaran dengan hati yang senang dan nyaman. Guru yang selalu menampilkan sifat rahmah akan menjadi teladan bagi siswanya. Hal ini sesuai dengan prinsip pendidikan karakter Islami ${ }^{37}$ :

a. Menjadikan Allah sebagai Tujuan

b. Memperhatikan perkembangan akal rasional

c. Memperhatikan perkembangan kecerdasan emosi

d. Praktik melalui keteladanan dan pembiasaan

e. Memperhatikan pemenuhan kebutuhan hidup

f. Menempatkan nilai sesuai prioritas

Sebagaimana yang diajarkan oleh Rasulullah, bahwa beliau dalam mengajarkan sahabat-sahabatnya banyak dengan keteladanan. Mendidik dengan keteladanan hanya efektif untuk aspek-aspek pendidikan yang bertujuan membentuk sikap dan keterampilan. Mengajar dengan keteladanan merupakan salah satu kunci keberhasilan dalam pendidikan. Manusia banyak belajar tentang berbagai kebiasaan dan tingkah laku melalui proses peniruan terhadap kebiasaan dan tingkah laku kedua orang tua, guru, atau bahkan kepada teman-temannya. Jika kita membuka kembali lembaran sejarah tentang bagaimana Rasulullah mendidik para sahabatnya, maka kita akan mendapatkan informasi bahwa dalam praktiknya Nabi Muhamammad Shallallahu 'alaihi wa sallam justru lebih mengutamakan sikap arif dan lemah lembut dalam mendidik para sahabat. Salah satu contohnya adalah hadits berikut ini:

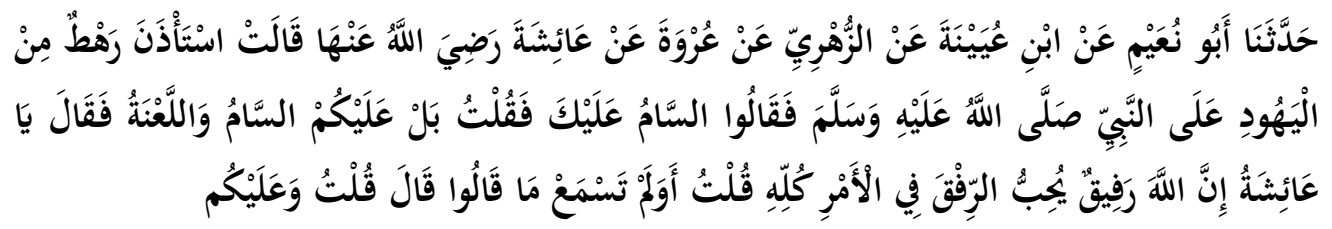

Terjemahannya: Telah menceritakan kepada kami Abu Nu'aim dari Ibnu Uyainah dari Az Zuhri dari Urwah dari Aisyah radliallahu 'anha mengatakan; Sekelompok orang yahudi meminta izin kepada Nabi shallallahu 'alaihi wasallam dan mengucapkan; 'Assaam 'alaika (semoga kematian tertimpa kepada kalian), saya menjawab; 'bal 'alaikum Assam wal la'nah (Bahkan untuk kalian kematian dan juga laknat).' Maka Nabi berujar; 'hai Aisyah, bahwasanya Allah menyukai kelembutan dalam segala urusan.' Saya menjawab; 'Tidakkah engkau mendengar apa yang

37 Erma Pawitasari. 6 Prinsip Pendidikan Karakter Islami. Dalam "Islamia: Jurnal Pemikiran Islam". Republika:17 Januari 2013. 
mereka ucapkan? ' Beliau menjawab: "Saya menjawab; wa'alaikum (bahkan untuk kalian)." (HR al-Bukhariy) ${ }^{38}$

Sikap lemah lembut dan penuh kasih sayang inilah yang justru menanamkan kesan mendalam di hati para sahabat. Sehingga mereka mudah menerima pencerahan dari Nabi SAW. Terdapat teks hadits yang menginformasikan bahwa orang tua boleh memukul anaknya, yaitu:

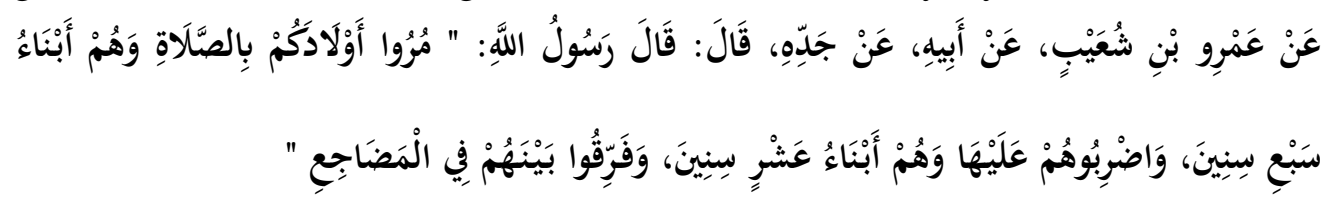

Terjemahannya: Perintahkanlah anak-anak kalian untuk shalat saat mereka usia tujuh tahun dan pukullah mereka saat usia sepuluh tahun. Dan pisahkan tempat tidur mereka." (HR Abu Dawud). ${ }^{39}$

Akan tetapi, hadits yang membolehkan orang tua untuk memukul anaknya saat usia 10 tahun sebenarnya perlu dipahami secara kontekstual dan sesuai perkembangan zaman, sehingga tidak menimbulkan masalah baru. ${ }^{40}$ Dalam arti bahwa yang menjadi tujuan pokok adalah pendidikan. Adapun "memukul" hanyalah salah satu cara teknis yang menjadi opsi terakhir. Itupun dengan tambahan ketentuan bahwa secara eksplist, pukulan itu tidak boleh dilakukan di wajah. ${ }^{41}$ Seorang guru yang mendidik dengan rahmah, bukan berarti dia tidak boleh memberikan hukuman (punishment) kepada siswanya. Memberikan hukuman sekalipun adalah juga merupakan bagian dari rahmah, sehingga dia akan berhati-hati dalam memberikan hukuman.

Guru yang memiliki sifat rahmah adalah merupakan bagian dari adab/akhlak yang mulia. Tujuan utama ilmu dalam Islam bukanlah untuk meraih keuntungan ekonomi yang pada akhirnya bermuara pada kepentingan duniawi. Dalam Islam, tujuan utama ilmu adalah untuk membentuk adab/akhlak yang baik. Untuk meraih adab dan akhlak yang tinggi, maka peran guru menjadi sangat penting. Guru merupakan model bagi pembentukan keilmuan dan karakter anak didik. Guru yang menyuarakan kebenaran dan kebaikan akan membawa kesan yang mendalam pada diri siswa. Guru yang memiliki adab dan akhlak yang tinggi, jiwa yang kuat, pengetahuan yang mumpuni, akan membentuk anak didik yang mumpuni dan berintegritas. Guru sangat berperan dalam menanamkan ilmu sekaligus akhlak ke dalam jiwa murid. Sebaik apa pun kurikulumnya, apabila

${ }^{38}$ Lidwa Pusaka i-Software - Kitab 9 Imam Hadist

${ }^{39}$ I-Software Jawami' al-Kalim. Islamweb.com

40 Ali Imron, Re-Interpretasi Hadis Tarbawi Tentang Kebolehan Memukul Anak Didik, dalam Jurnal Pendidikan Islam. Fakultas Tarbiyah dan Keguruan UIN Sunan Kalijaga Yogyakarta. Volume I, Nomor 2, Desember 2012, 155. 148-149.

${ }^{41}$ Ali Imron, Re-Interpretasi Hadis Tarbawi Tentang Kebolehan Memukul Anak Didik...., 
guru tidak memiliki jiwa pendidik, keikhlasan, pengorbanan, perjuangan, maka kurikulum itu pun tidak akan membawa kebaikan. Sebaliknya, jika jiwa pendidik dari seorang guru diintensifkan, semangat keikhlasan dan pengorbanan dikembangkan, kemampuan guru ditinggikan, maka akan membawa dampak yang lebih baik bagi dunia pendidikan itu sendiri. ${ }^{42}$

\section{3. 'Ilm (Kompetensi Pedagogik / Kompetensi Profesional)}

Karakteristik ideal yang harus dimiliki oleh guru diantaranya adalah 'ilm. Karakter ini jika dikaitkan dengan kompetensi, maka masuk dalam kategori kompetensi pedagogik atau bahkan bisa dikategorikan sebagai kompetensi profesional. Salah satu syarat terpenting untuk menjadi seorang guru adalah 'Ilm (Knowledge), mempunyai pengetahuan yang cukup perihal pendidikan. Ilmu yang harus dimiliki oleh guru mencakup segala macam ilmu (yang bermanfaat), terutama yang berkaitan dengan ilmu dari ajaran agama. Sebab ajaran agama (alQuran dan al-Hadits) juga merupakan sumber ilmu dalam pandangan Islam. Pentingnya syarat berilmu ini adalah karena guru adalah orang yang bertanggung jawab dalam membimbing siswa untuk mencapai tujuan dari pendidikan itu sendiri.

Guru memiliki tugas ganda yaitu di samping mengajar, dia juga harus senantiasa belajar. Karena sifat dari Ilmu adalah dinamis, selalu berkembang seiring dengan perkembangan kehidupan manusia itu sendiri. Apalagi sekarang adalah zaman di mana ilmu pengetahuan dan teknologi berkembang dengan pesatnya. Maka seorang guru tidak boleh merasa cukup dengan ilmu yang dia miliki. Dia harus selalu meng-update ilmunya dengan cara seperti: selalu membaca, sering melibatkan diri dalam berbagai kegiatan ilmiah baik itu berupa seminar, dialog, sarasehan, konferensi, workshop, bedah buku, studi banding, sandwich, research fellow, penelitian, dan penulisan karya ilmiah baik untuk jurnal, makalah seminar, buku ilmiah, pengantar buku karya orang lain, penyuntingan, penerjemahan, buku modul, diktat, dan sebagainya. ${ }^{43}$ Dengan cara seperti inilah guru akan mampu menjawab berbagai tantangan yang berkaitan dengan pendidikan. Ilmu yang dimiliki oleh guru tidak sebatas hanya kepada materi saja, namun juga berkaitan dengan ilmu tentang metode, strategi, pendekatan dalam mentransfer ilmu itu kepada siswanya. Dengan memiliki ilmu yang mendalam, maka guru akan dapat melaksanakan tugasnya dengan baik, inilah yang disebut dengan kompetensi profesional. Terdapat lima (5) indikator guru yang memiliki kompetensi profesional ${ }^{44}$ yaitu sebagai berikut:

42 Adnin Armas, Adab, Guru dan Kurikulum, Dalam "Islamia: Jurnal Pemikiran Islam”. Republika: 16 Mei 2013.

${ }^{43}$ Mujammil Qomar, Strategi Pendidikan Islam, (Jakarta: Erlangga, 2013), 147-148 Guru, 10 .

${ }^{44}$ Permendiknas RI Nomor 16 Tahun 2007. Standar Kualifikasi Akademik dan Kompetensi 
a. Menguasai materi, struktur, konsep, dan pola pikir keilmuan yang mendukung mata pelajaran yang diampu.

b. Menguasai standar kompetensi dan kompetensi dasar mata pelajaran/bidang pengembangan yang diampu.

c. Mengembangkan materi pembelajaran yang diampu secara kreatif.

d. Mengembangkan keprofesionalan secara berkelanjutan dengan melakukan tindakan refektif.

e. Memanfaatkan teknologi informasi dan komunikasi untuk mengembangkan diri.

Dalam pandangan ajaran Islam, segala sesuatu harus dilakukan secara rapi, benar, tertib, dan teratur. Proses-prosesnya harus diikuti dengan baik. Sesuatu tidak boleh dilakukan secara asal-asalan. Hal ini merupakan prinsip utama dalam ajaran Islam yang merupakan perwujudan nilai-nilai manajemen yang terdapat dalam ajaran Islam. Bahkan dalam ajaran Islam, bekerja secara profesional merupakan salah satu sebab untuk mendapatkan kecintaan dari Allah Subhanahu wa Ta'ala sebagaimana sabda Nabi Muhammad Shallallahu 'alaihi wa Sallam berikut:

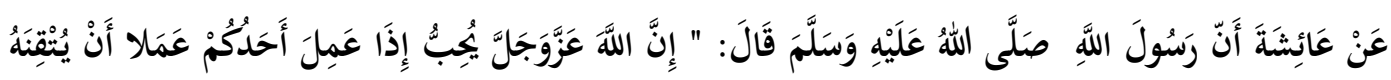

Terjemahannya: 'Sesungguhnya Allah Azza wa Jalla mencintai seseorang yang apabila bekerja, dia mengerjakannya secara terampil (profesional)." (HR Thabraniy dan Bayhaqiy). ${ }^{45}$

\section{Penutup}

Tugas seorang guru adalah tugas yang penuh tanggung jawab. Maka untuk memudahkan dalam melaksanakan tanggung jawab tersebut, guru dituntut untuk selalu meningkatkan kompetensinya. Guru tidak boleh merasa cukup dengan kualitas yang dia miliki. Dia harus selalu mendekatkan diri kepada Tuhan (tugas 'abdun), menjadi pribadi yang penuh rahmah dan memiliki kompetensi maksimal dengan jalan inilah guru akan selalu mendapatkan bimbingan Allah dalam setiap aktivitasnya. Menjadi guru adalah pekerjaan yang berat, namun dengan demikianlah kedudukan seorang guru menjadi mulia. Pada akhirnya pemerintah diharapkan agar terus menerus memperhatikan keadaan dari para guru, baik berupa peningkatan kompetensi/kualitas guru, maupun kesejahteraan bagi para guru. Selain itu, seorang guru memiliki tugas ganda yaitu di samping mengajar, dia juga harus senantiasa belajar. Karena sifat dari Ilmu adalah dinamis, selalu

\footnotetext{
${ }^{45}$ I-Software Jawami' al-Kalim. Islamweb.com
} 
berkembang seiring dengan perkembangan kehidupan manusia itu sendiri. Apalagi sekarang adalah zaman di mana ilmu pengetahuan dan teknologi berkembang dengan pesatnya. Maka seorang guru harus selalu meng-update ilmunya dengan cara seperti: selalu membaca, sering melibatkan diri dalam berbagai kegiatan ilmiah baik itu berupa seminar, dialog, sarasehan, konferensi, workshop, bedah buku, maupun studi banding serta tidak boleh merasa cukup dengan ilmu yang dia miliki guna meningkatan layanan mutu pendidikan dan peningkatan profesionalitasnya sebagai seoreang guru yang handal.

\section{DAFTAR PUSTAKA}

Ahmad bin Faris bin Zakariya, Abi Al-Husain. Mu'jam Maqayis al-Lugah, Juz 4, Beirut: Dar al-Fikr, 1979 M/1399H.

al-Husain bin Muhammad al-Ma'ruf Bi al-Ragib al-Ashfahani, Abi al-Qasim , AlMufaradat fi Garib al-Qur'an, Juz 2, Beirut:Dar Fikr, t.th

Al-Qaththan, Manna'. Pengantar Studi Ilmu Al-Quran. Jakarta: Pustaka AlKautsar, 2006.

Armas, Adnin. Adab, Guru dan Kurikulum. Dalam "Islamia: Jurnal Pemikiran Islam”. Republika: 16 Mei 2013.

Arif, Syamsuddin. Filsafat Ilmu Islami. Dalam "Islamia: Jurnal Pemikiran Islam". Republika: 21 Februari 2013.

Az-Zuhayliy, Wahbah. Tafsir al-Munir: fi al-Aqidah wa asy-Syari'ah wa alManhaj. Jilid 8: Juz 15-16. Damaskus: Daarul Fikr, 2009.

Fahmi Zarkasyi, Hamid. Kurikulum Pendidikan. Dalam "Islamia: Jurnal Pemikiran Islam". Republika: 16 Mei 2013.

Fahmi Zarkasyi, Hamid. Membangun Peradaban Islam Dengan Ilmu Pengetahuan. Makalah Kuliah Umum disampaikan pada Pembukaan Program Pasca Sarjana Bidang Pendidikan Islam, Universitas Ibn Khaldun, Bogor, Kampus Universitas Ibn Khaldun, Bogor, tanggal 11 Agustus 2007.

Fathurrahman, Muhammad dan Sulistyorini. Meretas Pendidikan Berkualitas dalm Pendidikan Islam (Menggagas Pendidik atau Guru yang Ideal dan Berkualitas dalam Pendidikan Islam). Cetakan I. Yogyakarta: Teras, 2012.

Fuad 'Abd al-Baqi, Muhammad. Mu 'jam al-Mufahras li al-Faz al-Qur'an Cet. I. Kairo: Dar al-Kutub al-Mishriyah, $1364 \mathrm{H}$.

I-Software Jawami’ al-Kalim. Islamweb.com

Imron, Ali. Re-Interpretasi Hadis Tarbawi Tentang Kebolehan Memukul Anak Didik. Dalam Jurnal Pendidikan Islam. Fakultas Tarbiyah dan Keguruan UIN Sunan Kalijaga Yogyakarta. Volume I, Nomor 2, Desember 2012.

Izzan, Ahmad dan Saehudin. Tafsir Pendidikan, Studi Ayat-ayat Berdimensi Pendidikan. Cetakan I. Tangerang: Pustaka Aufa Media (PAM Pres), 2012.

Janawi. Kompetensi Guru: Citra Guru Profesional. Bandung: Alfabeta, 2011

Lidwa Pusaka i-Software - Kitab 9 Imam Hadist 
Mendikas. Undang-Undang RI Nomor 14 tahun 2005 tantang Guru dan Dosen. Cetakan I. Yogyakarta: Pustaka Yustisia, 2006.

Muchlis. Kompetensi Pendidik Dalam Pendidikan Islam Perspektif Al-Qur'an (Telaah Tafsir Al-Mishbah Surah Al- 'Alaq). Tesis: Tidak dipublikasikan.

Muhaimin. Pemikiran dan Aktualisasi Pengembangan Pendidikan Islam. Cetakan I. Jakarta: Rajawali Pers, 2011

Mukrim bin Manzur al-Fariqi al-Misri, Muhammad bin. Lisan al-'Arabi. Juz 3 Cet. I. Beirut: Dar Sadir, t.th.

Nata, Abuddin. Filsafat Pendidikan Islam, Jakarta: Gaya Media Pratama, 2005.

Nata, Abuddin. Tafsir Ayat-ayat Pendidikan (Tafsir al-Ayat al-Tarbawy). Cetakan I. Jakarta: PT Raja Grafindo Persada, 2002.

Pawitasari, Erma. 6 Prinsip Pendidikan Karakter Islami. Dalam "Islamia: Jurnal Pemikiran Islam". Republika:17 Januari 2013.

Permendiknas RI Nomor 16 Tahun 2007. Standar Kualifikasi Akademik dan Kompetensi Guru.

Qomar, Mujammil. Strategi Pendidikan Islam. Jakarta: Erlangga, 2013

Quraish Shihab, M.. Ensiklopedia al-Qur'an: Kajian Kosa Kata. Cet. I. Jakarta: Lentera Hati, 2007.

Quraish Shihab, M. Wawasan al-Qur'an; Tafsir Tematik Atas Pelbagai Persoalan Umat Bandung: Mizan, 2014.

Raharjdo, Dawam. Ensiklopedi al-Qur'an Jakarta: Paramadina, 1996.

Rosyadi, Khoiron. Pendidikan Profetik. Yogyakarta: Pustaka Pelajar, 2004.

Saleh Abdullah, Abdurrahman. Teori-teori Pendidikan Berdasarkan al-Qur'an Jakarta: Rineka Cipta, 2007.

Tafsir, Ahmad. Ilmu Pendidikan dalam Perspektif Islam. Bandung: Remaja Rosdakarya, 2008.

Tim Penyusun Kamus Pusat Bahasa, Kamus Bahasa Indonesia. Jakarta: Pusat Bahasa, 2008.

Uzer Usman, Moh. Menjadi Guru Profesional. Bandung : Remaja. 2001.

Umar, Bukhari. Ilmu Pendidikan Islam. Cetakan I. Jakarta: Amzah, 2010.

Warson Munawwir, Ahmad. Al-Munawwir Kamus Arab Indonesia. Cet. XIV. Surabaya: Pustaka Progressif, 1997.

https://www.harakatuna.com/makna-rahmat-dalam-al-quran-al-karim.html diakses 03 Desember 2018, pukul 10.30. 